\title{
STANDAR SARANA DAN PRASARANA PENDIDIKAN
}

\author{
Baiq Rohiyatun \\ Admiinistrasi Pendidikan, FIP IKIP Mataram \\ Email: rbaiq@yahoo.co.id
}

\begin{abstract}
Abstrak: Sarana dan prasarana yang dimiliki sekolah merupakan faktor pendukung terlaksananya program sekolah, khususnya kegiatan pembelajaran yang dilakukan guru. Sarana dan prasarana yang dimiliki sekolah harus dikelola dengan baik, dengan tujuan jika warga sekolah hendak memerlukan atau menggunakannya, maka sarana dan prasarana tersebut dalam keadaan siap pakai. Menurut perspektif pemerintah, kegiatan manajemen sarana dan prasarana pendidikan setidak-tidaknya memiliki delapan (8) mata rantai kegiatan. Sementara menurut Peraturan Menteri No. 24 Tahun 2007 bahwa Standar Nasional Pendidikan tentang Sarana dan Prasarana mencakup tujuh (7) kegiatan manajemen. Guna mengoptimalkan pengadaan, penyaluran, inventarisasi, pemeliharaan, penyimpanan dan pengahapusan sarana dan prasarana pendidikan, maka diperlukan perencanaan yang matang, sehingga sekolah dituntut untuk memiliki kemandirian untuk mengatur dan mengurus sekolah menurut kebutuhan berdasarkan aspirasi dan partisipasi warga sekolah dengan tetap mengacu pada peraturan dan perundangan-undangan yang berlaku. Pengelolaan sarana dan prasarana di sekolah itu memang harus di kelola secara baik dengan perencanaan yang baik pula. Sarana dan prasarana pendidikan sangatlah bermanfaat dan berperan penting untuk menunjang kelancaran proses pendidikan karena meskipun KBM (kegiatan Belajar Mengajar) sudah baik, namun tidak didukung dengan alat-alat atau sarana prasarana pendidikan maka hasil yang dicapai tidak akan sesempurna yang diharapkan. Untuk itu perhatian terhadap pengelolaan semua sarana dan prasarana atau perlengkapan di sekolah memang harus di prioritaskan demi terealisasinya tujuan utama dari adanya perlengkapan ini mampu mendukung penyuksesan dalam pembelajaran.
\end{abstract}

Kata Kunci: Standar, Sarana, Prasarana, Pendidikan

\section{PENDAHULUAN}

Dalam kehidupan manusia salah satu aspek yang sangat penting adalah pendidikan. Melalui pendidikan manusia dapat mengetahui dan mempelajari berbagai cara untuk meningkatkan dan mengembangkan potensi berupa intelektual, mental, sosial, emosional dan kemandirian dalam kehidupan sehingga menghasilkan manusia yang berkualitas dan mampu menjawab tantang zaman. Dunia pendidikan harus diperlakukan dan dikelola secara professional, karena semakin ketatnya persaingan dalam lembaga pendidikan. Jika lembaga pendidikan dikelola seadanya maka akan ditinggalkan konsumen atau masyarakat.

Dalam UU Sisdiknas (Sistem Pendidikan Nasional ) No. 20 Tahun 2003, pada Bab VII Pasal 42 dengan tegas disebutkan bahwa; (1) Setiap satuan pendidikan wajib memiliki sarana yang meliputi perabot, peralatan pendidikan, media pendidikan, buku dan sumber belajar lainnya, bahan habis pakai, serta perlengkapan lain yang diperlukan untuk menunjang proses pembelajaran yang teratur dan berkelanjutan. (2) Sarana dan prasarana pendidikan juga menjadi salah satu tolok ukur dari mutu sekolah. Untuk itu diperlukan pemahaman dan pengaplikasian manajemen sarana dan prasarana pendidikan persekolahan berbasis sekolah. Bagi pengambil kebijakan di sekolah pemahaman tentang sarana dan prasarana akan membantu memperluas wawasan tentang bagaimana ia dapat berperan dalam merencanakan, menggunakan dan mengevaluasi sarana dan prasarana yang ada sehingga dapat dimanfaatkan dengan optimal guna mencapai tujuan pendidikan. Manajemen sekolah akan efektif dan efisien apabila didukung oleh sumber daya manusia yang profesional untuk mengoperasikan sekolah, terpenuhinya komponen komponen yang menunjang pengoptimalan belajar mengajar dalam sebuah sekolah. Yang mana, sarana prasarana sekolah yang salah satu dalam komponen tersebut tentunya sebagai kepala sekolah yang merupakan menejer dalam sekolah memperperhatikan secara maksimal dalam memenuhi sarana prasarana sekolah yang di kelolanya.

Sebuah SD/MI sekurang-kurangnya memiliki prasarana sebagai berikut: ruang kelas, ruang perpustakaan, laboratorium 
IPA, ruang pimpinan, ruang guru, tempat peribadah, ruang UKS, jamban, gudang, ruang sirkulasi, dan tempat bermain/berolahraga. Sebuah SMP/MTs sekurang-kurangnya memiliki prasarana sebagai berikut: ruang kelas, ruang perpustakaan, ruang laboratorium IPA, ruang pimpinan, ruang guru, ruang tata usaha, tempat beribadah, ruang konseling, ruang UKS, ruang organisasi kesiswaan, jamban, gudang, ruang sirkulasi, tempat bermain/berolahraga. Sebuah SMA/MA sekurang-kurangnya memiliki prasarana sebagai berikut: ruang kelas, ruang perpustakaan, ruang laboratorium biologi, ruang laboratorium fisika, ruang laboratorium kimia, ruang laboratorium computer, ruang laboratorium bahasa, ruang pimpinan, ruang guru, ruang tata usaha, tempat beribadah, ruang konseling, ruang UKS, ruang organisasi kesiswaan, jamban, gudang, ruang sirkulasi, dan tempat bermain/berolahraga.

\section{PEMBAHASAN}

\section{PENGERTIAN MANAJEMEN SARANA DAN PRASARANA}

Pengelolaan lembaga atau instansi bisa berjalan dan menjadi sebuah lembaga yang profesional tergantung dari cara mengurus, mengelola, dan mengatur lembaga tersebut. Manajemen berasal dari kata To Manage yang artinya mengatur. Pengaturan dilakukan melalui proses dan diatur berdasarkan urutan dan fungsi-fungsi manajemen itu. G.R. Terry menyatakan bahwa manajemen adalah satu proses yang khas yang terdiri dari tindakan tindakan perencanaan, pengorganisasian, pengarahan dan pengendalian yang dilakukan untuk menentukan serta mencapai sasaran-sasaran yang telah ditentukan melalui pemanfaatan sumber daya manusia dan sumber-sumber Lainnya. Jadi manajemen itu merupakan suatu proses untuk mewujudkan tujuan yang diinginkan Ada kaitan yang erat antara organisasi, administrasi dan manajemen. Administrasi dan manajemen tidak dapat dipisahkan dan harus merupakan suatu kesatuan, hanya saja kegiatannya yang dapat dibedakan sesuai dengan perbedaan kedua wawasan. Administrasi lebih sempit dari manajemen, dalam administrasi tercakup dalam manajemen. Secara spesifik administrasi merupakan satu bidang dari manajemen sebab manajemen terdiri dari enam bidang, yakni production, marketing, financial, personal, human relation dan administrative management (Suharsimi Arikunto 1993).

Menurut Echols dan Shadily (2005) manajemen berasal dari bahasa Inggris dengan kata kerja to manage yang artinya mengurus, mengatur, melaksanakan dan mengelola. Manajemen secara bahasa berarti bagaimana proses mengurus, mengatur, melaksanakan dan mengelola kegiatankegiatan dalam sebuah instansi atau organisasi untuk mencapai tujuan. Menurut Hasibuan (2007) Manajemen adalah ilmu dan seni mengatur proses pemanfaatan sumber daya manusia dan sumber-sumber lainnya secara efektif dan efisien untuk mencapai suatu tujuan tertentu. Menurut Rohiat (2006) Manajemen sarana dan prasarana adalah kegiatan yang mengatur untuk mempersiapkan segala peralatan/material bagi terselenggaranya proses pendidikan di sekolah. Manajemen sarana dan prasarana dibutuhkan untuk membantu kelancaran proses belajar mengajar. Manajemen sarana dan prasarana dapat diartikan sebagai kegiatan menata, mulai dari merencanakan kebutuhan, pengadaan, penyimpanan dan penyaluran, pendayagunaan, pemeliharaan, penginventarisan dan penghapusan serta penataan lahan, bangunan, perlengkapan, dan perabot sekolah serta tepat guna dan tepat sasaran (Sobri 2009). Manajemen sarana dan prasarana pendidikan dapat didefinisikan sebagai proses kerja sama pendayagunaan semua sarana dan prasarana pendidikan secara efektif dan efisien.( Bafadal,2003).

Berdasarkan pengertian diatas maka dapat disimpulkan bahwa manajemen adalah suatu proses yang terdiri dari rangkaian kegiatan, seperti perencanaan, penggerakan atau pengendalian/pengawasan, yang 
dilakukan untuk menentukan dan mencapai tujuan yang telah ditentukan melalui pemanfaatan sumberdaya manusia dan sumberdaya lainnya secara efektif dan efisien. Manajemen sarana dan prasarana yang baik diharapkan dapat menciptakan sekolah yang bersih, rapi, dan indah sehingga menciptakan kondisi yang menyenangkan baik bagi guru maupun murid untuk berada di sekolah. Di samping itu juga tersedianya alat-alat atau fasilitas belajar yang memadai secara kuantitatif, kualitatif, dan relevan dengan kebutuhan serta dapat dimanfaatkan secara optimal untuk kepentingan proses pendidikan dan pengajaran, baik oleh guru sebagai pengajar maupun siswa sebagai pelajar. Manajemen sarana dan prasarana yang baik diharapkan dapat menciptakan sekolah yang bersih, rapi, dan indah sehingga menciptakan kondisi yang menyenangkan baik bagi guru maupun murid untuk berada di sekolah. Di samping itu juga tersedianya alat-alat atau fasilitas belajar yang memadai secara kuantitatif, kualitatif, dan relevan dengan kebutuhan serta dapat dimanfaatkan secara optimal untuk kepentingan proses pendidikan dan pengajaran, baik oleh guru sebagai pengajar maupun siswa sebagai pelajar.

\section{SARANA DAN PRASARANA PENDIDIKAN}

Ketentuan dari Badan Standar Nasional Pendidikan maka setiap satuan pendidikan harus bisa merencanakan pengadaan sarana dan prasarana sekolah agar proses belajar mengajar berlangsung secara efektif dan efisien. Dalam menyusun perencanaan sarana dan prasarana sekolah harus direncanakan dengan baik dan cermat sehingga mampu memenuhi kebutuhan sarana dan prasarana sekolah tersebut. Prasarana pendidikan adalah semua perangkat kelengkapan dasar yang secara tidak langsung menunjang proses pendidikan di sekolah. Dalam pendidikan misalnnya lokasi atau tempat, bangunan sekolah, lapangan olahraga, ruang dan sebagainya. Sarana dan prasarana adalah semua benda atau barang yang bergerak maupun yang tidak bergerak yang digunakan untuk menunjang terlaksanakannya proses pembelajaran yang langsung maupun yang tidak langsung dalam sebuah pendidikan (Rohit 2006). Sarana pendidikan adalah segala macam peralatan yang digunakan guru untuk memudahkan penyampaian materi pelajaran. Jika dilihat dari sudut murid, sarana pendidikan adalah segala macam peralatan yang digunakan murid untuk memudahkan mempelajari mata pelajaran. Prasarana pendidikan adalah segala macam peralatan, kelengkapan, dan benda-benda yang digunakan guru (dan murid) untuk memudahkan penyelenggaraan pendidikan. Sarana pendidikan dan prasarana pendidikan memiliki perbedaan seperti pada fungsi masing-masing, yaitu sarana pendidikan untuk "mempelajari materi pelajaran/memudahkan penyampaian, "sedangkan prasarana pendidikan untuk "memudahkan kegiatan/ penyelenggaraan pendidikan." Dalam makna inilah sebutan "digunakan langsung" dan "digunakan tidak langsung" dalam proses pendidikan.

Dari beberapa uraian diatas, definisi ini menunjukkan bahwa sarana dan prasarana yang ada di sekolah perlu didayagunakan dan dikelola untuk kepentingan proses pembelajaran di sekolah. Pengelolaan itu dimaksudkan agar dalam menggunakan sarana dan prasarana di sekolah bisa berjalan dengan efektif dan efisien. Pengelolaan sarana dan prasarana merupakan kegiatan yang amat penting di sekolah, karena keberadaannya akan sangat mendukung terhadap suksesnya proses pembelajaran disekolah. Menurut peraturan Menteri Pendidikan Nasional Nomor 24 Tahun 2007 Tanggal 28 Juni 2007 tentang standar sarana dan prasarana untuk Sekolah Dasar/Madrasah Ibtidaiyah (SD/MI) adalah : Bangunan gedung memenuhi persyaratan kesehatan berikut;

1. Mempunyai fasilitas secukupnya untuk ventilasi udara dan pencahayaan yang memadai. 
2. Memiliki sanitasi di dalam dan di luar bangunan gedung untuk memenuhi kebutuhan air bersih, pembuangan air kotor dan/atau air limbah, kotoran dan tempat sampah, serta penyaluran air hujan.

3. Bahan bangunan yang aman bagi kesehatan pengguna bangunan gedung dan tidak menimbulkan dampak negatif terhadap lingkungan.tandar Sarana dan Prasarana yang Seharusnya.

\section{SARANA PRASARANA YANG MENUNJANG PEMBELAJARAN}

1. Sarana Yang Menunjang Proses Pembelajaran, meliputi :

a) Peralatan pendidikan adalah sarana yang secara langsung digunakan untuk pembelajaran. Seperti papan tulis, spidol, dll.

b) Media pendidikan adalah peralatan pendidikan yang digunakan untuk membantu komunikasi dalam pembelajaran.

c) Buku adalah karya tulis yang diterbitkan sebagai sumber belajar, meliputi:Buku teks pelajaran adalah buku pelajaran yang menjadi pegangan peserta didik dan guru untuk setiap mata pelajaran.Buku pengayaan adalah buku untuk memperkaya pengetahuan peserta didik dan guru.Buku referensi adalah buku rujukan untuk mencari informasi atau data tertentu.

d) Sumber belajar lainnya adalah sumber informasi dalam bentuk selain buku meliputi jurnal, majalah, surat kabar, poster, situs (website), dan compact disk.

2. Prasarana Yang Menunjang Proses Pembelajaran, Meliputi :

a) Ruang kelas adalah ruang untuk pembelajaran teori dan praktik yang tidak memerlukan peralatan khusus.

b) Ruang perpustakaan adalah ruang untuk menyimpan dan memperoleh informasi dari berbagai jenis bahan pustaka. c) Ruang laboratorium adalah ruang untuk pembelajaran secara praktik yang memerlukan peralatan khusus.

d) Ruang pimpinan adalah ruang untuk pimpinan melakukan kegiatan pengelolaan sekolah/madrasah.

e) Ruang guru adalah ruang untuk guru bekerja di luar kelas, beristirahat, dan menerima tamu.

f) Ruang tata usaha adalah ruang untuk pengelolaan administrasi sekolah/madrasah.

g) Ruang konseling adalah ruang untuk peserta didik mendapatkan layanan konseling dari konselor berkaitan dengan pengembangan pribadi, sosial, belajar, dan karir.

h) Ruang UKS adalah ruang untuk menangani peserta didik yang mengalami gangguan kesehatan dini dan ringan di sekolah/madrasah.

i) Tempat beribadah adalah tempat warga sekolah/madrasah melakukan ibadah yang diwajibkan oleh agama masing-masing pada waktu sekolah.

j) Ruang organisasi kesiswaan adalah ruang untuk melakukan kegiatan kesekretariatan pengelolaan organisasi peserta didik.

k) Jamban adalah ruang untuk buang air besar dan/atau kecil.

1) Gudang adalah ruang untuk menyimpan peralatan pembelajaran di luar kelas, peralatan sekolah/madrasah yang tidak/belum berfungsi, dan arsip sekolah/madrasah.

m) Tempat berolahraga adalah ruang terbuka atau tertutup yang dilengkapi dengan sarana untuk melakukan pendidikan jasmani dan olah raga.

n) Tempat bermain adalah ruang terbuka atau tertutup untuk peserta didik dapat melakukan kegiatan bebas.

\section{KETENTUAN SARANA DAN PRASARANA}

Sebuah Sekolah sekurang-kurangnya memiliki prasarana sebagai berikut: 1 . ruang 
kelas, 2. ruang perpustakaan, 3. laboratorium IPA, 4. ruang pimpinan, 5. ruang guru, 6 . tempat beribadah, 7. ruang UKS, 8. jamban, 9. gudang, 10. ruang sirkulasi, 11. tempat bermain/berolahraga.

Ketentuan mengenai prasarana tersebut beserta sarana yang ada di dalamnya diatur dalam standar sebagai berikut:

1. Ruang Kelas

a) Fungsi ruang kelas adalah tempat kegiatan pembelajaran teori, praktek yang tidak memerlukan peralatan khusus, atau praktek dengan alat khusus yang mudah dihadirkan.

b) Banyak minimum ruang kelas sama dengan banyak rombongan belajar.

c) Kapasitas maksimum ruang kelas 28 peserta didik.

d) Rasio minimum luas ruang kelas $2 \mathrm{~m} 2 /$ peserta didik. Untuk rombongan belajar dengan peserta didik kurang dari 15 orang, luas minimum ruang kelas $30 \mathrm{~m} 2$.

e) Lebar minimum ruang kelas 5 $\mathrm{m}$.

f) Ruang kelas memiliki fasilitas yang memungkinkan pencahayaan yang memadai untuk membaca buku dan untuk memberikan pandangan ke luar ruangan.

g) Ruang kelas memiliki pintu yang memadai agar peserta didik dan guru dapat segera keluar ruangan jika terjadi bahaya, dan dapat dikunci dengan baik saat tidak digunakan.

h) Ruang kelas dilengkapi sarana sebagai berikut:

1.1 Prabotan

1. buah kursi/ peserta didik, kursi harus kuat, stabil dan mudah dipindahkan oleh pesera didik

2. Meja peserta didik 1 buah/peserta didik. Meja harus kuat, stabil, dan mudah dipindahkan oleh peserta didik. Ukuran sesuai dengan kelompok usia peserta didik dan mendukung pembentukan postur tubuh yang baik, minimum dibedakan untuk kelas 1-3 dan kelas 4-6. Desain memungkinkan kaki peserta didik masuk dengan leluasa ke bawah meja.

3. Kursi guru 1 buah/guru. Kursi harus kuat, stabil, dan mudah dipindahkan. Ukuran memadai untuk duduk dengan nyaman.

4. Meja guru 1 buah/guru Kuat, stabil, dan mudah dipindahkan. Ukuran memadai untuk bekerja dengan nyaman.

5. Lemari 1 buah/ruang Ukuran memadai untuk menyimpan perlengkapan yang diperlukan kelas. Tertutup dan dapat dikunci.

6. Rak hasil karya peserta didik 1 buah/ruang. Ukuran memadai untuk meletakkan hasil karya seluruh peserta didik yang ada di kelas. Dapat berupa rak terbuka atau lemari.

7. Papan pajang 1 buah/ruang Ukuran minimum $60 \mathrm{~cm} \times 120$ $\mathrm{cm}$.

2. Peralatan Pendidikan

Alat peraga [lihat daftar sarana laboratorium IPA]

\section{Media Pendidikan}

Papan tulis 1 buah/ruang Ukuran minimum $90 \mathrm{~cm} \quad \mathrm{x} 200 \mathrm{~cm}$. Ditempatkan pada posisi yang memungkinkan seluruh peserta didik melihatnya dengan jelas.

1.2 Perlengkapan Lain

1. Tempat sampah 1 buah/ruang

2. Tempat cuci tangan 1 buah/ruang

3. Jam dinding 1 buah/ruang

4. Soket listrik 1 buah/ruang

2. Ruang Perpustakaan

a) Ruang perpustakaan berfungsi sebagai tempat kegiatan peserta 
didik dan guru memperoleh informasi dari berbagai jenis bahan pustaka dengan membaca mengamati, mendengar, dan sekaligus tempat petugas mengelola perpustakaan.

b) Luas minimum ruang perpustakaan sama dengan luas satu ruang kelas. Lebar minimum ruang perpustakaan $5 \mathrm{~m}$.

c) Ruang perpustakaan dilengkapi jendela untuk memberi pencahayaan yang memadai untuk membaca buku.

d) Ruang perpustakaan terletak di bagian sekolah yang mudah dicapai

e) Ketentuan sarana perpustakaan yaitu:

2.1 Buku

1. Buku teks pelajaran 1 eksemplar/mata

pelajaran/peserta didik, ditambah 2 eksemplar/mata pelajaran/sekolah Termasuk dalam daftar buku teks pelajaran yang ditetapkan oleh Mendiknas dan daftar buku teks muatan lokal yang ditetapkan oleh Gubernur atau Bupati/Walikota.

2. Buku panduan pendidik 1 eksemplar/mata pelajaran/guru mata pelajaran bersangkutan, ditambah 1 eksemplar/mata pelajaran/sekolah

3. Buku pengayaan 840 judul/sekolah Terdiri dari $60 \%$ non-fiksi dan $40 \%$ fiksi. Banyak eksemplar/sekolah minimum: 1000 untuk 6 rombongan belajar, 1500 untuk 7-12 rombongan belajar, 2000 untuk 13-24 rombongan belajar.

4. Buku referensi 10 judul/sekolah Sekurangkurangnya meliputi Kamus Besar Bahasa Indonesia, kamus Bahasa Inggris, ensiklopedi, buku statistic daerah, buku telepon, kitab undang-undang dan peraturan, dan kitab suci.

5. Sumber belajar lain 10 judul/sekolah Sekurangkurangnya meliputi majalah, surat kabar, globe, peta, gambar pahlawan nasional, CD pembelajaran, dan alat peraga matematika.

\subsection{Perabot}

1. Rak buku 1 set/sekolah Dapat menampung seluruh koleksi dengan baik. Memungkinkan peserta didik menjangkau koleksi buku dengan mudah.

2. Rak majalah 1 buah/sekolah Dapat menampung seluruh koleksi majalah. Memungkinkan peserta didik menjangkau koleksi majalah dengan mudah.

3. Rak surat kabar 1 buah/sekolah Dapat menampung seluruh koleksi suratkabar. Memungkinkan peserta didik menjangkau koleksi suratkabar dengan mudah.

4. Meja baca 10 buah/sekolah Kuat, stabil, dan mudah dipindahkan oleh peserta didik. Desain memungkinkan kaki peserta didik masuk dengan leluasa ke bawah meja.

5. Kursi baca 10 buah/sekolah Kuat, stabil, dan mudah dipindahkan oleh peserta didik. Desain dudukan dan sandaran membuat peserta didik nyaman belajar.

6. Kursi kerja 1 buah/petugas Kuat dan stabil. Ukuran yang memadai untuk bekerja dengan nyaman.

7. Meja kerja/ sirkulasi 1 buah/petugas. Kuat, stabil, dan mudah dipindahkan. 
Ukuran yang memadai untuk bekerja dengan nyaman.

8. Lemari katalog 1 buah/sekolah Cukup untuk menyimpan kartu-kartu katalog. Lemari katalog dapat diganti dengan meja untuk menempatkan katalog.

9. Lemari 1 buah/sekolah Ukuran memadai untuk menampung seluruh peralatan untuk pengelolaan perpustakaan. Dapat dikunci.

10. Papan pengumuman 1 buah/sekolah Ukuran minimum $1 \mathrm{~m} 2$.

11. Meja multimedia 1 buah/sekolah Kuat dan stabil. Ukuran memadai untuk menampung

12. seluruh peralatan multimedia. 2.3 Media Pendidikan

Peralatan multimedia 1 set/sekolah Sekurangkurangnya terdiri dari 1 set komputer (CPU, monitor minimum 15 inci, printer), TV, radio, dan pemutar VCD/DVD.

2.4 Perlengkapan Lain

1. Buku inventaris 1 buah/sekolah

2. Tempat sampah 1 buah/ruang

3. Soket listrik 1 buah/ruang

4. Jam dinding 1 buah/ruang

3. Ruang Pimpinan

a) Ruang pimpinan berfungsi sebagai tempat melakukan kegiatan pengelolaan sekolah, pertemuan dengan sejumlah kecil guru, orang tua murid, unsure komite sekolah, petugas dinas pendidikan, atau tamu lainnya.

b) Luas minimum ruang pimpinan $12 \mathrm{~m} 2$ dan lebar minimum $3 \mathrm{~m}$.

c) Ruang pimpinan mudah diakses oleh guru dan tamu sekolah, dapat dikunci dengan baik.

d) Ruang pimpinan dilengkapi sarana berikut :
3.1 Perabot

1. Kursi pimpinan 1 buah/ruang Kuat dan stabil. Ukuran memadai untuk duduk dengan nyaman.

2. Meja pimpinan 1 buah/ruang Kuat dan stabil. Ukuran memadai untuk bekerja dengan nyaman.

3. Kursi dan meja tamu 1 set/ruang Ukuran memadai untuk 5 orang duduk dengan nyaman.

4. Lemari 1 buah/ruang Ukuran memadai untuk menyimpan perlengkapan pimpinan sekolah. Tertutup dan dapat dikunci.

5. Papan statistik 1 buah/ruang Berupa papan tulis berukuran minimum $1 \mathrm{~m} 2$.

3.2 Perlengkapan lain

1. Simbol kenegaraan 1 set/ruang Terdiri dari Bendera Merah Putih, Garuda Pancasila, Gambar Presiden RI, dan Gambar Wakil Presiden RI.

2. 2.Tempat sampah 1 buah/ruang

3. 3.Mesin ketik/computer 1 set/sekolah

4. 4.Filing cabinet 1 buah/sekolah

5. 5.Brankas 1 buah/sekolah

6. 6.Jam dinding 1 buah/ruang

4. Ruang Guru

a. Ruang guru berfungsi sebagai tempat guru bekerja dan istirahat serta menerima tamu, baik peserta didik maupun tamu lainnya.

b. Rasio minimum luas ruang guru 4 $\mathrm{m} 2 /$ pendidik dan luas minimum $32 \mathrm{~m} 2$.

c. Ruang guru mudah dicapai dari halaman sekolah ataupun dari luar lingkungan sekolah, serta dekat dengan ruang pimpinan.

d. Ruang guru dilengkapi sarana sebagai berikut: 
4.1 Perabot

1. Kursi kerja 1 buah/guru Kuat dan stabil. Ukuran memadai untuk duduk dengan nyaman.

2. Meja kerja 1 buah/guru Kuat dan stabil. Model meja setengah biro. Ukuran memadai untuk menulis, membaca, memeriksa pekerjaan, dan memberikan konsultasi.

3. Lemari 1 buah/guru atau 1 buah yang digunakan bersama oleh semua guru Ukuran memadai untuk menyimpan perlengkapan guru untuk persiapan dan pelaksanaan pembelajaran. Tertutup dan dapat dikunci.

4. Papan statistik 1 buah/sekolah Berupa papan tulis berukuran minimum $1 \mathrm{~m} 2$.

5. Papan pengumuman 1 buah/sekolah Berupa papan tulis berukuran minimum 1 $\mathrm{m} 2$.

4.2 Perlengkapan Lain

1. Tempat sampah 1 buah/ruang

2. Tempat cuci tangan 1 buah/ruang

3. 2.Jam dinding $1 \mathrm{buah} / \mathrm{ruang}$

4. 3.penanda waktu 1 buah/sekolah

5. Jamban

a. Jamban berfungsi sebagai tempat buang air besar dan/atau kecil.

b. Minimum terdapat 1 unit jamban untuk setiap 60 peserta didik pria, 1 unit jamban untuk setiap 50 peserta didik wanita, dan 1 unit jamban untuk guru.

c. Banyak minimum jamban setiap sekolah 3 unit.

d. Luas minimum 1 unit jamban $2 \mathrm{~m} 2$.

e. Jamban harus berdinding, beratap, dapat dikunci, dan mudah dibersihkan. f. Tersedia air bersih di setiap unit jamban.

g. Jamban dilengkapi sarana sebagai berikut:

5.1 Perlengkapan Lain

1. Kloset jongkok 1 buah/ruang Saluran berbentuk leher angsa.

2. Tempat air 1 buah/ruang Volume minimum 200 liter. Berisi air bersih.

3. Gayung 1 buah/ruang

4. Gantungan pakaian 1 buah/ruang

5. Tempat sampah 1 buah/ruang

6. Tempat Bermain/Berolahraga

a. Tempat bermain/berolahraga berfungsi sebagai area bermain, berolahraga, pendidikan jasmani, upacara, dan kegiatan ekstrakurikuler.

b. Rasio minimum luas tempat bermain/berolahraga $3 \mathrm{~m} 2 /$ peserta didik. Untuk satuan pendidikan dengan banyak peserta didik kurang dari 167, luas minimum tempat bermain/berolahraga 500 $\mathrm{m} 2$. Di dalam luasan tersebut terdapat ruang bebas untuk tempat berolahraga berukuran $20 \mathrm{~m} \times 15$ $\mathrm{m}$.

c. Tempat bermain/berolahraga yang berupa ruang terbuka sebagian ditanami pohon penghijauan.

d. Tempat bermain/berolahraga diletakkan di tempat yang tidak mengganggu proses pembelajaran di kelas.

e. Tempat bermain/berolahraga tidak digunakan untuk tempat parkir.

f. Ruang bebas yang dimaksud di atas memiliki permukaan datar, drainase baik, dan tidak terdapat pohon, saluran air, serta bendabenda lain yang mengganggu kegiatan olahraga.

g. Tempat bermain/berolahraga dilengkapi sarana sebagai berikut:

6.1 Peralatan Pendidikan 
1. Tiang bendera 1 buah/sekolah Tinggi sesuai ketentuan yang berlaku.

2. Bendera 1 buah/sekolah Ukuran sesuai ketentuan yang berlaku.

3. Peralatan bola voli 1 set/sekolah Minimum 6 bola.

4. Peralatan sepak bola 1 set/sekolah Minimum 6 bola.

5. Peralatan senam 1 set/sekolah Minimum matras, peti loncat, tali loncat, simpai, bola plastik, tongkat.

6. Peralatan atletik 1 set/sekolah Minimum lembing, cakram, peluru, tongkat estafet, dan bak loncat.

7. Peralatan seni budaya 1 set/sekolah Disesuaikan dengan potensi masingmasing satuan pendidikan.

8. Peralatan ketrampilan 1 set/sekolah Disesuaikan dengan potensi masingmasing satuan pendidikan.

6.2 Perlengkapan Lain

1. Pengeras suara $1 \mathrm{set} / \mathrm{sekolah}$

2. Tape recorder 1 buah/sekolah

7. Laboratorium IPA
a. Laboratorium IPA dapat memanfaatkan ruang kelas.
b. Sarana laboratorium IPA berfungsi sebagai alat bantu mendukung kegiatan dalam bentuk percobaan.
c. Setiap SD/MI dilengkapi sarana laboratorium IPA seperti :

7.1 Perabot

Lemari 1 buah/sekolah Kuat, stabil, dan aman. Ukuran memadai untuk menyimpa seluruh alat peraga. Tertutup dan dapat dikunci. Dapat memanfaatkan lemari yang terdapat di ruang kelas.

7.2 Peralatan Pendidikan

1. Model kerangka manusia 1 buah/sekolah

Tinggi minimum $125 \mathrm{~cm}$. Mudah dibawa.

2. Model tubuh manusia 1 buah/sekolah Tinggi minimum $125 \mathrm{~cm}$. Dapat diamati dengan mudah oleh seluruh peserta didik. Dapat dibongkar pasang. Mudah dibawa.

3. Globe 1 buah/sekolah Diameter minimum $40 \mathrm{~cm}$. Memiliki penyangga dan dapat diputar. Dapat memanfaatkan globe yang terdapat di ruang perpustakaan.

4. Model tata surya 1 buah/sekolah Dapat mendemonstrasikan terjadinya fenomena gerhana.

5. Kaca pembesar 6 buah/sekolah

6. Cermin datar 6 buah/sekolah

7. Cermin cekung 6 buah/sekolah

8. Cermin cembung 6 buah/sekolah

9. Lensa datar 6 buah/sekolah

10. Lensa cekung 6 buah/sekolah

11. Lensa cembung 6 buah/sekolah

12. Magnet batang 6 buah/sekolah Dapat mendemonstrasikan gaya magnet.

13. Poster IPA, terdiri dari:

a) metamorfosis,

b) hewan langka,

c) hewan dilindungi,

d) tanaman khas Indonesia,

e) contoh ekosistem

f) sistem-sistem pernapasan hewan, 1set/sekolah Jelas terbaca dan berwarna, ukuran minimum A1.

\section{KESIMPULAN}

Pengelolaan sarana dan prasarana di sekolah itu memang harus di kelola secara baik dengan perencanaan yang baik pula. Sarana 
dan prasarana pendidikan sangatlah bermanfaat dan berperan penting untuk menunjang kelancaran proses pendidikan karena meskipun KBM (kegiatan Belajar Mengajar) sudah baik, namun tidak didukung dengan alat-alat atau sarana prasarana pendidikan maka hasil yang dicapai tidak akan sesempurna yang diharapkan. Untuk itu perhatian terhadap pengelolaan semua sarana dan prasarana atau perlengkapan di sekolah memang harus di prioritaskan demi terealisasinya tujuan utama dari adanya perlengkapan ini mampu mendukung penyuksesan dalam pembelajaran.

\section{DAFTAR PUSTAKA}

Bafadal,. Ibrahim, 2003, Seri Manajemen Peningkatan Mutu Pendidikan Berbasis
Sekolah, Manajemen Perlengkapan Sekolah Teori dan Aplikasi, Cet. 1, PT. Bumi Aksara, Jakarta.

Depdiknas. Undang-undang RI Nomor 20 Tahun 2003 tentang Sistem Pendidikan Nasional.

Echols, John M. dan Shadily, Hassan. 2005. Kamus Inggris Indonesia. Jakarta: Gramedia

Hasibuan, Malayu. 2007. Manajemen Dasar, Pengertian, dan Masalah. Jakarta: Bumi Aksara

Rohiat. 2006. Manajemen Sekolah: Teori Dasar dan Praktik. Bandung: Refika Aditama.

Mattin \& Nurhattati Fuad, Manajemen Sarana dan Prasarana Pendidika: Konsep dan Aplikasinya ( Jakarta: PT Rajagrafindo, 2016)

Suharsimi Arikunto, Organisasi dan Administrasi Pendidikan Teknologi dan Kejuruan, Cet II, (jakarta: PT GrafindoPersada, 1993) hal, 82

Sobri. 2009. Pengelolaan Pendidikan. Yogyakarta: Multi Pressindo.

Suryani, nunuk. ( 2012 ). Strategi Belajar Mengajar. Yogyakarta: Penerbit Ombak. 